\title{
Reformulation of Fostering Corruption in Correctional Institution
}

\author{
Darmawati \\ Doctoral Student, Faculty Of Law, Hasanuddin University, and \\ Lecturer Of Law, Faculty Of Law, Ichsan Gorontalo University, Indonesia
}

\begin{abstract}
Corruption is an extraordinary crime and requires special attention in guiding corruption inmates. Guidance on corruption inmates is carried out differently from general prisoners, this difference is done through the classification of prisoners as well as with indicators of evaluating the implementation of prisoners' coaching, this is done so that in guiding corruption inmates can be more comprehensive and effectively carried out in Correctional Institutions.
\end{abstract}

Keywords: Fostering Corruption, Classification of Prisoners, Correctional Institutions.

DOI: $10.7176 / \mathrm{JAAS} / 62-04$

Publication date:March $31^{\text {st }} 2020$

\section{A. Introduction}

Penitentiary is one of the institutions of the criminal justice sub-system that has a strategic function in the implementation of imprisonment as well as a place for fostering prisoners (hereinafter referred to as WBP) who have committed crimes. The existence of correctional institutions (hereinafter referred to as Lapas) becomes an important thing to foster prisoners so that after undergoing the criminal process in prison, prisoners are aware of their actions and do not repeat the mistakes that have been made and can be accepted again by the community.

Corruption is an extra ordinary crime because criminal acts of corruption tend to be committed by those who have high social status, both in terms of their position in work before entering prison, as well as their education and economic level. Corruption is an extraordinary crime because the victims caused by corruption are very large.

Corruption is an extraordinary crime that is often carried out in a planned, systematic manner and damages the joints of national economic life. ${ }^{1}$ Corruption as an extraordinary crime makes the nation not only static, but experiences a significant setback.

Corruption is a major crime that is complex and its eradication cannot be carried out normally, but is prosecuted in extraordinary ways. In addition, corruption is also classified as a white collar crime (white collar crime) because the perpetrators are mostly intellectual people.

The act of corruption is very detrimental to the country's finances or the country's economy and impedes national development, so it must be eradicated in order to create a just and prosperous society based on Pancasila and the 1945 Constitution of the Republic of Indonesia.

Corruption is widespread in the community. Progress continues to increase from year to year, both in the number of cases and the amount of state financial losses. Uncontrolled corruption will be a disaster not only for national economic life, but also for the life of the nation in general. ${ }^{2}$

Considering that corruption is an extraordinary crime and must be dealt with seriously by the government and the community from its prevention to the implementation of fostering corruption inmates in correctional institutions, a precise approach is needed so that what is intended for correctional purposes can be realized.

In addition to criminal fines, one of the types of sentences that can be imposed on corruption perpetrators is imprisonment. The imprisonment is carried out in prison. Sukamiskin Class I Lapas Bandung is a special institution appointed to foster corruption inmates even though Sukamiskin Class I Lapas Bandung is not fully inhabited by corruption inmates.

Prison is a place to conduct inmates training which sometimes the objectives expected in the correctional process are not achieved optimally. Detaining and fostering corruption convicts who previously had political power and great influence on the government is not an easy thing.

Coaching conducted in prisons should ideally pay attention to prisoners' backgrounds before they enter prison. This is needed in coaching so that maximum results are achieved.

Based on the provisions of Article 12 Paragraph (1) of the Penal Code, it is explained that: ${ }^{3}$

In the context of fostering prisoners in prisons, a classification is carried out on the basis of:

a. age,

\footnotetext{
${ }^{1}$ Arif Suhartono, Said Karim, Marwati Riza. 2019. Criminal Accountability Against Illegal Civil Servant Salary Receipt in Criminal Acts of Corruption. Papua Law Journal. Volume 3 Issue 2 May 2019.

2 Agus Salim, Aswanto, Muhadar, Syamsuddin Muchtar. 2016. Harmonization Of Inter-Institutional Authority In Eradicate Corruption. International Journal Of Scientific And Technology Research Volume 5, Issue 10, October 2016.

${ }^{3}$ Law Number 12 of 1995 Concerning Penitentiary.
} 
b. gender,

c. long time criminal imposed,

d. type of crime, and

e. other criteria according to the needs or development of the guidance.

Classifying prisoners for coaching purposes is indeed necessary, both in terms of security and maintaining negative influences that can affect other prisoners. Based on the results of the Pre-Research conducted by the author, it is found that the classification based on age and sex for the purpose of coaching has been carried out by the prison, in this case it can be seen by the separation of special prisons for Children and Adults. In addition, the classification based on gender can also be seen with the establishment of special prisons for women.

Placement of prisoners in prison is done by placing prisoners in blocks / rooms that have been classified based on the length of the criminal and the type of crime. However, in the implementation of coaching is still carried out thoroughly without seeing the classification based on the types of crimes as mentioned in Article 12 Paragraph (1) of the Penitentiary Act so that the form and method of coaching are the same for all prisoners.

According to the Institute for Criminal Justice Reform (ICJR) notes, since the enactment of the Sukamiskin Penitentiary in 2012 to 2017, no clear picture of what fostering convicts is fostered. The more stringent form of supervision promised by the Government is refuted by the findings of various investigations in the prison. ${ }^{1}$

Talking about the arrangement of guiding corruption inmates is the same as guiding prisoners in general, namely referring to the Correctional Act which is further explained in the PP Guidance and Guidance for WBP. The process of fostering corruption inmates is divided into several stages starting from the stages of admission, orientation, observation, assimilation stages and finally the stages of integration. All stages must be passed by all corruption convicts before they leave prison.

The stages of the process of guiding and guiding prisoners certainly cannot be separated from correctional officers who have an important role in it. Correctional officers must have good qualities as educators, parents, coaches, as guards so that in the implementation of the coaching process can run smoothly.

The provisions in Article 8 of the Penitentiary Law stated that correctional officers are functional law enforcement officials who carry out tasks in the field of guidance, security and guidance of WBP. Correctional Officers as functional officials are bound to uphold the integrity of the profession in carrying out Correctional missions. Upholding the integrity of the Correctional Officer's profession in the context of service and coaching in correctional institutions and mentoring through Bapas.

Obstacles in carrying out training in correctional facilities include quality and quantity problems from correctional officers. The lack of correctional officers and the quality or level of knowledge of correctional officers when confronted with corrupt prisoners is certainly not yet optimal in terms of conducting a coaching process in prisons. So it is natural that the prisoner guidance program cannot be implemented as programmed by the prison. ${ }^{2}$

In addition, most of the correctional officers have not been supported by the provision of skills in conducting coaching with a humanist approach that can touch the feelings of prisoners and be able to be creative in conducting coaching. ${ }^{3}$

In fact, there are still many obstacles encountered in carrying out the process of guiding corruption inmates. This is due to the absence of special rules governing the formation of corrupt prisoners so that the forms of coaching are equated with other prisoners without classification. ${ }^{4}$ Even though the special prison for corruption, Sukamiskin prison, has been provided to accommodate corruption inmates. Placement of prisoners of corruption in Sukamiskin Prison originated from the idea of the Ministry of Justice and Ham because they saw the prison as having separate cells where one prisoner was placed in his own cell. But in reality, not all corrupt prisoners are placed in these prisons but there are also in other prisons.

\section{B. The Corruption Prisoners Classification System}

According to the Big Indonesian Dictionary, classification is a systematic arrangement in groups or groups according to established rules or standards. Classifying corruption inmates is a process, method, act of classifying corruption prisoners into prisons for the purpose of fostering. The classification system for prisoners of corruption is the initial stage that prisoners must pass before the implementation of the training process in correctional institutions.

Classification according to Glase, Wilkins and Title states that the process is in the interest of determining and for showing corrective agents, the unit unit that determines the difference in supervision and handling of violators. ${ }^{5}$

\footnotetext{
icjr.or.id, Accessed on 16 Maret 2019.

${ }^{2}$ Deliana. 2007. Implementasi Ide Individualisasi Pidana Dalam Pelaksanaan Pembinaan Narapidana. Jurnal Hukum Pro Justitia, Vol.25 No.2. p. 105.

${ }^{3}$ Heru Susetyo. 2012. Laporan Tim Pengkaji Hukum Tentang Sistem Pembinaan Narapidana Berdasarkan Prinsip Restorative Justice. Badan Pembinaan Hukum

Nasional Kementerian Hukum dan HAM RI. p.5

${ }^{4}$ Zulfikri. Kendala Yang Dihadapi Lembaga Pemasyarakatan Atas Tidak. Adanya Pembinaan Bagi Narapidana Korupsi. Universitas Indonesia. Jakarta

${ }^{5}$ Glaser, Wilkins, Title. 1977. Correctional Institution (Classification of Offenders). United States. J.B. Lippincott Company. p. 21
} 
Guidance for inmates must provide alternative coaching methods that can be made a choice by each prisoner with different backgrounds and characteristics. Correctional officers in conducting coaching cannot generalize because in general prisoners who are in prisons have different characters.

To be able to classify prisoners first, an assessment of prisoners is conducted. This assessment is carried out when a convict first goes through a prison term in prison. This assessment is useful to determine the coaching program that will be given to corruption prisoners by conducting an assessment of risks that arise both for themselves and / or others including officers, crimes committed, social background owned by prisoners and their coaching needs which include placement or coaching program. These individual assessments are important to ensure that actions are taken to minimize risk and recognize the community's needs that are possible in the social reintegration process. On the basis of the assessment, each corruption convict was classified according to a record of crimes committed, the character of the convicted corrupt, their influence on the government, treatment needs including safety categories and placement in accordance with the results of the assessment conducted.

Based on the provisions of the Minister of Law and Human Rights Regulation No. 12 of 2013 concerning risk assessments and needs assessments for prisoners and correctional clients explained that the risk assessment is an assessment conducted to determine the level of prisoners' risk in taking action in prisons. A needs assessment is an assessment carried out to determine the most appropriate guidance needs for inmates based on factors that contribute to the criminal offenses committed. Risk assessment can be conducted periodically to review the results of the assessment before and after inmates undergo a training program.

This assessment must be carried out by trained assessors who have participated in and declared to have passed the assessment training and practice and meet the requirements as stipulated in the Minister of Law and Human Rights Regulation No. 12 of 2013 concerning risk assessments and needs assessments for prison inmates and clients.

Placement and classification of corruption prisoners is needed to provide an appropriate treatment in the implementation of coaching. This is because many of the coaching patterns provided do not fit the needs of prisoners and merely run the budget. For this reason, assessors are expected to be able to minimize errors in providing a guiding program for corruption inmates.

From the results of research that has been carried out in Sukamiskin Class I Lapas Lapas, the placement of corruption convicts has been placed based on the type of crime. Corruption convicts are placed in blocks that are different from other common prisoners. In addition, the cells in Lapas Sukamis may be occupied by one inmate one cell. Although in the case of the process of placement of prisoners have been separated based on the type of ration, the implementation of the coaching process is still carried out without any difference between corrupt prisoners and general prisoners.

Guidance for inmates will run optimally if prisoners are classified. In the provisions of Article 12 Paragraph (1) of Law Number 12 of 1995 Concerning Corrections, it states that:

In the framework of fostering inmates in prisons, the classification is based on:

a. Age

b. Gender

c. Long sentence imposed

d. Type of crime, and

e. Other criteria according to the needs or development of the guidance.

Based on Point 67, 68 the Standard Minimum Rules for the Treatment of Prisoners states that, the purpose of classifying inmates is: ${ }^{1}$

a. To separate from others, prisoners whose criminal records have a bad character tend to have a bad influence.

b. To divide prisoners into classes, to facilitate facilitation such as care and with a view to social rehabilitation.

c. As far as possible separate institutions are provided to be used as guidance for the class of imprisoned people.

The division of prisoners into classes, the prison regulation of 1917 set in a pattern called progressives. The purpose of progressive classification is the phasing of the formation that a prisoner goes through from the moment he enters until he is free. The provisions regarding this classification can be described as follows: ${ }^{2}$

Article 49:

Those sentenced to prison terms are divided into four ranks

Article 50:

Rank one is, a person who is sentenced to life imprisonment, someone who is sentenced to prison for a while who does not want to follow orders or who is dangerous for the safety of prison employees or imprisoned friends;

\footnotetext{
1 Standard Minimum Rules for the Treatment of Prisoners. Adopted by the First United Nations Congress on The Prevention of Crime and the Treatment of Offenders, held at Geneva in 1955, and approved by the Economic and Social Council by its resolutions 663 C (XXIV) of 31 July 1957 and 2076 (LXII) of 13 May 1977

${ }^{2}$ Koesnoen. 1961. Politik Penjara Nasional. Bandung. Sumur Bandung. p.39
} 
a person who is sentenced to prison for a temporary period and includes this, if his conduct for a good year, raised to the rank of two.

Article 51:

Second rank is a person sentenced to prison longer than three months at the beginning of his sentence, if they do not need to be assigned rank one, who was raised from rank one, or who was demoted from rank three.

Article 52:

In rank three are included people sentenced to prison from rank two, who for 6 consecutive months of good behavior. If his behavior is despicable, then a third rank sentence is reduced to a second rank.

Article 53:

In rank four, including people sentenced to prison for three months or less than three months.

Article 55:

People sentenced to prison who enter the rank of three, if he has served two-thirds and at least nine months of his sentence may be proposed to be released temporarily by agreement.

Furthermore, Sahardjo through his thoughts contained in ten basic principles of correctional use became guidelines for officers in carrying out their duties in prison. The basic principles of correctional matters related to the classification and placement of prisoners are: ${ }^{1}$

1) The state has no right The state has no right to make someone worse/more evil than before he entered the institution. For this reason a separation must be held between inmates:

a. The recidivists and not.

b. The criminal offenses are severe and mild

c. Types of criminal acts committed

d. Adults, young adults and children

e. Male and female

f. Convicts and detainees.

2) A new prison should be established in accordance with the needs of the implementation of a training program and moving institutions located in the middle of the city to places that are in accordance with the needs of the penal process. Prisoners' placement is adjusted to the classification as mentioned in point 1.

Based on the development of the penal system that the treatment of prisoners in the implementation of coaching in this case prisoners are applied as subjects and objects. Treatment as a subject means that inmates have similarities in equality as human beings so that they must be treated as humans as well. Treatment as an object that there are differences in position in fostering inmates according to their character.

Treatment of prisoners can be effective if prisoners feel the need to make changes, want to change, can accept changes and receive treatment in prison according to their needs. For this reason, a psychotherapy approach is needed as implemented in the United States that has guidelines, namely: "treatment of criminals can be effective, but only if they need to change, want to change, are amenable to change, and receive treatment that is matched to their need desire, and amenability to change." 2

According to the author, the approach is important to be used by the prison guardians to find out the extent of the coaching program that is being carried out by corruption inmates, so that changes can be seen in prisoners of corruption after undergoing training in correctional institutions.

If we look at the provisions contained in Article 12 Paragraph (1) of the Correctional Act, the implementation of classifying prisoners in Indonesia has been divided based on age as evidenced by the existence of child prisons to foster child inmates. The classification of prisoners based on age is intended so that adult prisoners, youth and children can be separated. Classification by sex has also been carried out in Indonesia by separating male and female prisoners, as evidenced by the existence of special prisons for women.

Classification based on the length of the sentence imposed based on observations made by the author in 3 (three) prisons in Indonesia the placement of prisoners has been classified based on the length of the crime in which prisoners are divided into:

1) B1 is specifically for inmates who have served a criminal term for more than 1 (one) year.

2) BII a is specifically for prisoners who undergo a crime of 3 (three) months to 1 (one) year.

3) BII $b$ is specifically for prisoners who undergo criminal 1 (one) day to 3 (three) months.

4) BIII s is specifically for prisoners who undergo criminal substitutes.

5) Lifetime specifically for prisoners who undergo life imprisonment.

Classifications based on types of crime have also been classified both in the Makassar Class I prison and class II prison in Yogyakarta, where prisoners are classified according to the type of crime, namely human trafficking, immigration, domestic violence, decency, corruption, currency, narcotics, traffic violations, murder, murder , money laundering, ill-treatment, embezzlement, fraud, robbery, banking, child protection, terrorism. The purpose

\footnotetext{
${ }^{1}$ Andi Hamzah, Siti Rahayu. 1983. Suatu Tinjauan Ringkas Sistem Pemidanaan di Indonesia. Jakarta. Akademika Pressindo. p. 87

${ }^{2}$ Logan dan Gaes. 1993. Meta Analysis and The Rehabilitation Of Punishment. ACJS. Vol. 10 No. 2. p.251
} 
of this classification is to eliminate prisonization ${ }^{1}$ prisoners. In addition, the purpose of the classification is to prevent the occurrence of coercion from the influence of one inmate on other prisoners, fights and so forth. For Sukamiskin Class I Prison in Bandung since 2012, this prison has been designated as a special prison for corruption cases, but in reality there are still public prisoners placed in the prison. In addition, the classification based on the type of crime has also been illustrated by the establishment of a special prison for narcotics that is spread in Indonesia.

The provisions of Article 12 Paragraph (1) of the Penitentiary Law state that "In the context of fostering prisoners in prisons, classification is carried out on the basis of: age, sex, length of sentence imposed, sex, and other criteria in accordance with the needs or development of coaching." The results of research conducted by the authors in several prisons show that for the benefit of coaching, prisoners have been differentiated on the basis of age and sex. This can be seen from the special prison for children and women. However, in the case of classification based on the type of crime and the length of crime in the construction process there is no separation. Classification based on the type of crime and the length of the crime is only done on the placement of prisoners in a room / block in prison.

Classification based on the type of crime according to the view of the author is important to do where the classification is not explained in detail in the explanation of the Penal Code. According to the author, classification based on the type of crime for coaching needs is separated from ordinary crime and extra ordinary crime.

Corruption convicts and other prisoners in terms of coaching are not divided so that the forms and methods of guiding prisoners are the same for all prisoners. This is due to the capacity of prisons that have exceeded the capacity (overcrowding), lack of supervisors, limited budget and the facilities and infrastructure in prisons are still limited. In fact, if we look at the intentions of classifying inmates as referred to in Article 12 Paragraph (1) of the Penitentiary Act, it is for criminal individualization that aims to foster prisoners according to the characteristics of prisoners.

Guidance on corruption inmates needs to get attention in updating the implementation of coaching. Guidance for inmates must be adjusted to the character of each prisoner. Models of fostering corruption inmates must be specifically designed and separated from public prisoners because the perpetrators of corruption have a high level of education and good intellectual abilities, therefore a special prison for corruption inmates is needed. This is done so that the implementation of inmate training is truly realized and understood by inmates so that what is the goal of coaching can be achieved.

If we look at the types of criminal acts of corruption based on Law Number 20 of 2001 concerning Amendments to Law Number 31 of 1999 concerning Eradication of Corruption, among others, it is detrimental to the country's finances, bribery, embezzlement in office, extortion, cheating, fraudulent interests in procurement and gratification.

Corruption is one of the many crimes that have a high risk because most of the corruption convicts have access and influence in prison. For this reason, corruption inmates are required to be placed in special prisons and provide training programs in coordination with relevant agencies. Therefore, the writer makes a formulation in Article 12 Paragraph (1) of the Correctional Act in the interest of fostering prisoners need to add classification on the basis of high risk prisoners. When viewed from its nature, corruption is one of the crimes that are extra ordinary crime. In addition, according to UNODC, corruption convicts are included in the high-risk prisoners indicators because some of the corruption convicts have money and previously had the power to influence the system in prison. One of the criteria for high-risk inmates is prisoners who according to the results of the assessment require special control efforts so that they adhere to the rules of the institution.

Based on the results of the interview the author with Mr. Azis Syamsuddin stated that in responding to and handling overcrowding and other problems in Lapas, it was necessary to improve management within Lapas. The need for the establishment of special prisons Narcotics, Corruption, Terrorism and other special criminal acts in order to reduce the potential problems that can arise as a form of Lapas theory which would become a "crime university". The weaknesses contained in the provisions of the Correctional Law regarding the provision of guidance for WBP are still very common and there is no mechanism for providing a more directed development program. $^{2}$

United Nations Offie for Project Service (UNOPS) in Technical Guidance for Prison Planning: Technical and Operational Considerations Based on the Standard Drinking Rules for the Treatment of Prisoners explains that the placement of prisoners who show high risk should ideally be placed in different safeguards and supervision, one of which with high security and supervision. ${ }^{3}$

UNODC provides guidance on high risk prisoners indicators that can be assessed from several aspects.

\footnotetext{
${ }^{1}$ The term Prisonization is used to describe the behavior of inmates with the aim of adjusting to life in prison, but in fact they refuse to obey the rules.

${ }^{2}$ Results of an Interview with the Chair of the Commission III of the Republic of Indonesia House of Representatives for the 2014-2019, 20 August 2019

${ }^{3}$ Shane Bryans and Tomris Atabay. 2016. Hand Book on the Management of High-Risk Prisoners (Criminal Justice Handbookseries). New York. UNODC
} 
Aspects of the assessment of prisoners seen from factors: ${ }^{1}$

1) Safety, endanger yourself, other prisoners or prison officers or visitors.

2) Stability, a threat to involvement in prisons, becomes a provocateur and is not cooperative.

3) Security, the possibility of escape.

4) Reoffendig, has the potential to commit serious / serious violations.

5) Society, detainees who still have relations related to organized crime, ideology of terrorism, drug trafficking networks or who have money and power to influence.

From the explanation above it can be seen that corruption is a crime that requires extraordinary handling. In terms of placement, corrupt prisoners fall into the category of high-risk prisoners.

To encourage the achievement of penal objectives, special guidance for corrupt prisoners needs to get attention both from the security aspect, correctional officers, and supporting facilities and infrastructure aspects, this is in the interests of effective coaching for prisoners, both corruption inmates and other general prisoners. To be able to lead to the effectiveness of coaching, a classification system is used to separate prisoners within prisons. The term used regarding the separation effort is classification. Edwin Sutherland explained that in the beginning, classification was only an attempt to distinguish prisoners for the purpose of discipline and administrative control based on criteria of age, sex, race, and whether prisoners were dangerous. However, in the 1920s and 1930s, classifications developed towards medical diagnosis models, such as disease diagnosis procedures. This development also led to the emergence of the concept of correction (correction). Classification in the correction system is then defined as a system of distinguishing prisoners according to the personal needs of the prisoners themselves, and (used to design and implement) individual-based programs according to the needs of the prisoners themselves. ${ }^{2}$

The results of the analysis of the author that in order to carry out coaching can be run in accordance with the objectives of correcting, the placement of corruption convicts is carried out on the basis of assessment assessments conducted by the assessors when corruption convicts first entered prison. From the results of the assessment of corruption convicts in conducting coaching divided into super maximum security prisons, maximum security prisons, medium security prisons and minimum security prisons.

Before corruption convicts are placed in prisons, an assessment is carried out to determine whether or not the corrupt convicts enter high-risk prisoners. If the results of the assessment of corruption convicts enter into highrisk inmates, then a placement in the maximum maximum security prisons will be carried out. Various treatment programs for guidance will be provided to corrupt prisoners and the development of behavior is monitored by the correctional guardians through a prisoner guidance evaluation system. Evaluation of the implementation of program delivery is carried out regularly with the aim of measuring the change in behavior of corrupt prisoners. For prisoners of corruption who have shown behavioral changes, they will be moved from Lapas Super Maximum Security to Lapa Maximum Security.

The coaching program implemented in the maximum security prison is focused on fostering behavior and discipline and fostering legal and intellectual awareness. Behavioral and disciplinary guidance, namely personal development that encourages changes in attitudes and behavior of prisoners of corruption that can increase faith and enhance the spirit of nationalism. The forms of behavioral and disciplinary guidance referred to are:

1) Fostering religious awareness, this coaching is organized to change the perspective and mindset of corrupt convicts in a positive direction as well as efforts to increase faith and piety in God Almighty.

2) Fostering national and state awareness, fostering activities on how to be a good citizen, can be of service to the nation and state and improve the spirit of nationalism.

3) Psychology Counseling, this form of coaching aims to strengthen motivation, reduce emotional stress, change bad habits, help inmates to develop their potential and help find solutions by exploring problems faced by corruption inmates.

The implementation of psychological counseling development is carried out at least every 1 (one) week 1 (one) time based on requests from corrupt prisoners considered by the Head of Prison and Guidance of prisoners through the TPP session. The forms of psychological therapy can be done by:

a. Behavioral modification techniques, namely changing prisoners' beliefs with positive new behaviors.

b. Humanistic therapy techniques, namely techniques with the approach of the phenomenology of personality that help realize the real self.

c. Cognitive therapy techniques, which provide or bring new information to inmates so that they can change expectations, beliefs, thinking strategies, from negative behaviors to better ones.

4) Rehabilitation is a coaching activity carried out in order to change the behavior of corrupt convicts to become individuals who do not conflict with applicable legal provisions.

\footnotetext{
${ }^{1}$ Ibid

${ }^{2}$ Edwin Sutherland. 1992. Principles of Criminology, 11th edition. New York. General Hall Inc. p. 479
} 
Development of legal and intellectual awareness in coaching programs in maximum security prisons, namely personal development that encourages changes in the attitudes and behavior of prisoners to be aware of mistakes, abide by the law and improve the thinking ability of prisoners of corruption. The forms of coaching are:

1) Promoting legal awareness, fostering with the aim of achieving a high level of legal awareness so that prisoners are aware of their mistakes, obey and obey the law, understand their rights and obligations as members of the community and obey the law.

2) Development of intellectual abilities, although corruption inmates have a high level of intellectual ability, but in the process of coaching is still needed in order to be able to support the positive activities carried out by corruption inmates during the training period in prison.

In addition, coaching is needed in the form of cooperation with other agencies, where corruption convicts are required to participate in a coaching program organized or facilitated by other agencies such as the Corruption Eradication Commission (KPK) with the approval of the Head of Prison through a TPP session decision. From the results of these activities, an assessment is made.

The coaching program in maximum security prisons is provided in accordance with the results of assessments and coaching contracts of corrupt prisoners, while the objective of holding maximum security prisons is to run a prisoner training program to encourage changes in the attitudes and behavior of prisoners who are aware of mistakes, abide by the law and order and increase discipline.

Prisoners from maximum security prisons who have shown changes in attitudes and behavior that are aware of mistakes, abide by the law and order as well as discipline in accordance with the results of the Litmas assessment recommended at the correctional observer team hearing placed in prison in the security medium.

The coaching program for prison in security medium is to foster independence and legal and intellectual awareness. The purpose of fostering independence is to increase the competence and ability of the prisoners themselves. In coaching in prison the security medium of prisoners is given the right to be able to carry out assimilation. This program is given in accordance with the results of the assessment and coaching contract.

Prisoners from Lapas Medium Security who have shown changes in attitudes and behavior, increased competence and self-capacity in accordance with the results of the assessment and litmas recommended at the correctional observer team session are placed in the Lapas minimum security. The training program at Lapas Minimum Security is in the form of fostering personalities with the aim of forming attitudes and behavioral changes, increasing the independence and productivity of prisoners.

The maximum security super prison places corruption inmates in one man one cell (one person, one inmate) without being given high security accessibility. Coaching is more focused on fostering personalities with the hope of giving birth to behavioral changes in the form of awareness, compliance, discipline, and reducing the level of risk for corrupt prisoners who have undergone coaching.

Placement of prisoners in maximum security prisons is done in groups in residential blocks with accessibility but limited. Prisoners are only in the residential block area, given access to attend the coaching program in the guidance / mosque room, communication with officers freely and communication with fellow prisoners is limited. Coaching is focused on fostering personalities with behavioral indicators giving birth to awareness, obedience and discipline to corrupt prisoners.

Placement of prisoners in prison security medium is the same as maximum prison security, which is done in groups in residential blocks. Prisoners are given accessibility in the form of access to outside prison within the framework of the assimilation program, access to conduct activities within the prison environment, communication with officers and fellow prisoners freely, and limited communication with families. The form of coaching is more focused on fostering independence with behavioral indicators in the form of awareness, compliance, discipline and skills.

Prisoners in Lapas minimum security are also placed in groups on residential blocks. Prisoners are allowed to do activities outside the prison environment. Communication with officers, prisoners and families is carried out freely. Coaching is focused on fostering independence in the form of production of goods / services and behavior change is expected in the form of awareness, compliance, discipline, skills and productivity.

Indicators of the successful implementation of the training program emphasize the principle of changing prisoners' behavior without being limited by time. The concept of coaching that will be given to inmates does not rely on time-staging guidelines based on the coaching pattern but rather focuses on the results achieved by inmates.

If related to the coaching theory that in order to successfully improve prisoners' behavior, each individual as a prisoner requires treatment according to their needs, as expressed by Herbert L Packer that: ${ }^{1}$

".... the rehabilitative ideal teaches us that we must treat each offender as an individual whose special needs and problems must be known as fully as possible in order to enable us to deal effectively with him. Punishment, in this view, must be forward looking. The gravity of the offense, however measured, may give us a clue to the intensity and duration of the measures needed to rehabilitate; but it is only a clue, not a

\footnotetext{
${ }^{1}$ Herbert L Packer. 1988. The Limit of The Criminal Sanction. California. Stanford University Press.
} 
prescription. There is, then, no generally postulated equivalence between the offense and the punishment, as there would be in the case of the retributive or even the detterent theory of punishment."

\section{Prisoner Guiding Assessment System}

The assessment system for prisoners' guidance is used to determine the placement of corruption prisoners in prisons and the form of guidance that will be given to them.

As in the United States, the development of thought that occurred in the 1970s made the assessment system a technology that would determine the success of the coaching program in prisons. The assessment system is considered to be able to increase the effectiveness of the coaching program in prisons from the term nothing works, to what's works. What works is a technology assessment term that shows that knowing the prisoner's needs and risks will determine what the program must intervene in. ${ }^{1}$

One of the weaknesses of the implementation of fostering prisoners in prison is that coaching is carried out just to fill the time during which prisoners serve their sentence. The success of the coaching program has not been clearly measured due to the absence of an assessment system used in the implementation of the coaching.

According to the author's analysis that in the framework of evaluating the implementation of prisoner guidance programs, a Prisoner Guiding Assessment System (SPPN) is needed. Prisoner Guidance Assessment System (SPPN) is a collection of information and data from corrupt prisoners related to coaching that has been undertaken connected to the Correctional Database System. To control the implementation of guidance for corruption convicts, SPPN is needed so that each implementation of guidance, whether it is personal development or independence, can be recorded in the system. Every corruption prisoner completes his coaching activities they are required to conduct a fingerprint (finger client) as a substitute for absence so that the prison guardian can control the involvement of prisoners in carrying out coaching through the system. In the assessment system for inmates' guidance the assessment scores of activities carried out by corrupt prisoners are aimed at fostering more effective, efficient, measurable, accurate and accurate prisoners. With a scoring system that is measured against the formation of prisoners, later the assessment will be used as a reference in the Corrections Observer Team session as part of fulfilling the rights of corrupt prisoners in submitting assimilation, parole, parole leave or parole leave.

The inclusion of corruption prisoners in various coaching programs in correctional institutions is part of the assessment in behavior change. The correctors and / or correctional guardians will make observations, identify changes in the behavior of corrupt prisoners and activities that have been followed by corrupt prisoners through an inmate guidance development (SPPN) evaluation system. The results of these observations will later become a benchmark in evaluating the success of fostering corruption inmates in correctional institutions.

If we refer to the essence of coaching that the realization of the implementation of coaching of corruption convicts is not entirely run optimally due to the absence of indicators of evaluation of the success of coaching based on the coaching pattern, although in this case the correctional officer has carried out coaching in accordance with applicable regulations, but the implementation of coaching has not been assessed run effectively.

The Assessment Indicators of the implementation of coaching in Lapas the authors describe as follows:

1) Maximum Security Lapas.

Appraisal instruments used in maximum security prisons where the correctional guardians assess prisoner instruments (behavior checklist). The aspects assessed include:

a. Religious Coaching includes compulsory worship, sunnah worship, religious studies, tolerance between religious communities, reading the holy book.

b. Aspects of nationalism include recognizing the sovereignty of the country, having national and state awareness.

c. Social aspects include obligations and prohibitions in prisons.

2) Lapas Medium Security

Appraisal indicators are used in the medium security prison where the correctional guardians assess prisoners' instruments (behavior checklist). The aspects assessed include:

a. Religious Coaching includes compulsory worship, sunnah worship, religious studies, tolerance between religious communities, reading the holy book.

b. Nationalism aspects include recognizing the sovereignty of the state, having national and state awareness, living four national pillars namely Pancasila, the 1945 Constitution of the Republic of Indonesia and Unity in Diversity.

c. Social aspects include obligations and prohibitions in prisons.

d. Aspects of work skills include knowledge, ways of working, work behavior, risks and work safety, production results and marketing.

3) Lapas Minimum Security

\footnotetext{
${ }^{1}$ Iqrak Sulhin. 2016. Diskontinuitas Penologi Punitif. Sebuah Analisis Genealogis Terbadap Pemenjaraan. Jakarta. Prenadamedia Group. Hal. 113
} 
Appraisal indicators are used in the minimum security prisons where the correctional guardians assess prisoners' instruments (behavior checklist). The aspects assessed include:

a. Religious Coaching includes compulsory worship, sunnah worship, religious studies, tolerance between religious communities, reading the holy book.

b. Aspects of nationalism include recognizing the sovereignty of the country, having national and state awareness.

c. Social aspects include obligations and prohibitions in prisons.

d. Production of goods / services.

Determination of assessment indicators is determined by the Directorate General of Corrections, where the indicator is divided into 2 namely the Personality program and the Independence Program. Sub-indicators of specific training programs for corruption inmates can be seen in the table below:

Table 1

Indicators of Corruption Prisoners Personality and Self Guidance Assessment:

\begin{tabular}{|ll|l|}
\hline \multicolumn{1}{|c|}{ Personality Development } & Fostering Independence \\
\hline 1) & Fear of God & 1. Service \\
2) & National and State Awareness & \\
3) & Intellectual & \\
4) & Attitudes and Behavior & \\
5) & Physical and spiritual health & \\
6) & Legal Awareness & \\
7) & Work activities & \\
\hline
\end{tabular}

The success of the implementation of guiding corruption inmates can be seen from the assessment indicators of fostering inmates. Where the assessment indicators are different from general prisoner assessment indicators. After the assessment indicators of the personality and independence development program are in place, then the weighting of each sub-indicator is needed. The score weights for each training for corruption convicts can be seen in the table below:

It is associated with one of the theories of criminal purpose stated by Plato quoted from Bambang Poernomo's book that giving a sanction and punishment to people who break the law is a must but must pay attention to the moral improvement of the perpetrators of crime. People who break the law must be punished, but punishment should not be seen as retaliation. Punishment aims to improve the moral attitude of the perpetrators of crime. ${ }^{1}$

In addition, one of the core of the implementation of coaching is the parameter of success of coaching. For this reason, the authors formulate the parameters of the success of the guiding program of corruption inmates in correctional services, which can be seen from the following indicators:

1) Corruption convicts have psychic abilities that enable them to admit mistakes, develop themselves and be tolerant and have changes in attitudes and behavior.

2) Corruption convicts have awareness in the religious field to repent immediately and control their behavior so that they return to the right path.

3) Corruption convicts are able to practice religious teachings that show compassion towards fellow human beings, create harmony in society and want to carry out congregational prayers in prison.

4) Corruption convicts have a sense of social responsibility both while in prison and are able to participate in the community at the time of reintegration.

5) Corruption convicts have good national insight and legal awareness.

For more details about the concept of the author about reformulating the system of guiding corruption in prison in prison, the authors describe in the table below:

\footnotetext{
${ }^{1}$ Bambang Poernomo. 2007. Pelaksanaan Pidana Penjara Dengan Sistem Pemasyarakatan. Yogyakarta. Liberty. P. 77
} 
Table 2

Reformulation of Corruption Prisoner Assistance System in Penitentiary

\begin{tabular}{|c|c|c|c|}
\hline $\mathrm{NO}$ & $\begin{array}{l}\text { Law Number } 12 \text { of } 1995 \\
\text { Concerning Penitentiary }\end{array}$ & Reformulation & Note \\
\hline \multirow[t]{2}{*}{1} & Article 12 & Article 12 & Article changes \\
\hline & $\begin{array}{l}\text { (1) In the framework of } \\
\text { fostering prisoners in prisons, } \\
\text { classification is carried out on } \\
\text { the basis of: } \\
\text { a. age } \\
\text { b. gender } \\
\text { c. long time sentence was } \\
\text { handed down } \\
\text { d. type of crime, and } \\
\text { e. other criteria according to the } \\
\text { needs or development of the } \\
\text { guidance }\end{array}$ & $\begin{array}{l}\text { (1) In the framework of fostering } \\
\text { prisoners in prisons, classification } \\
\text { is carried out on the basis of: } \\
\text { a. Age } \\
\text { b. gender } \\
\text { c. long time sentence was handed } \\
\text { down } \\
\text { d. type of crime, and } \\
\text { e. high risk inmates }\end{array}$ & $\begin{array}{l}\text { One of the criteria for high- } \\
\text { risk prisoners is prisoners who } \\
\text { according to the results of the } \\
\text { assessment require special } \\
\text { control efforts so that they } \\
\text { obey the rules of the } \\
\text { institution and prisoners who } \\
\text { are at risk of intimidating, } \\
\text { influencing or controlling } \\
\text { others to commit criminal } \\
\text { acts. High-risk inmates } \\
\text { include corruption inmates. }\end{array}$ \\
\hline & & $\begin{array}{l}\text { Article } 12 \\
\text { (1) Prisoners in Article } 12 \\
\text { Paragraph (1) point e are } \\
\text { placed in certain prisons } \\
\text { according to the results of } \\
\text { the assessment }\end{array}$ & $\begin{array}{l}\text { The prison in question is: } \\
\text { 1. Super Maximum Security } \\
\text { 2. Maximum Security } \\
\text { 3. Medium Security } \\
\text { 4. Minimum Security }\end{array}$ \\
\hline 2 & & $\begin{array}{l}\text { In the framework of evaluating the } \\
\text { implementation of prisoner } \\
\text { guidance programs the Prisoner } \\
\text { Guiding Assessment System } \\
\text { (SPPN) is used. }\end{array}$ &  \\
\hline
\end{tabular}

\section{Conclusion}

The form of a system of guiding corruption in prison in prison to realize the purpose of correcting is to classify corruption prisoners before coaching. To be able to do the classification must go through an assessment process by the assessor to determine the coaching program that will be given to corruption inmates and their placement in prison. With the classification of corruption convicts, the implementation of coaching can be carried out without merging with other public prisoners. In addition, an evaluation system is needed in the implementation of the program for guiding corruption inmates in controlling the course of coaching. In the assessment system for guiding prisoners and also making indicators for evaluating the implementation of coaching programs to see the changes that occur in prisoners of corruption after undergoing a series of coaching in prison.

\section{References}

Achmad Ruslan. Pidato Pengukuhan Guru Besar Fakultas Hukum Unhas Dalam Buku Kapita Selekta Ilmu Hukum. Edisi I. Makassar. Membumi Publishing.

Achmad Ruslan. 2013. Pembentukan Peraturan Perundang-Undangan di Indonesia. Yogyakarta. Rangkang Education.

Andi Hamzah, Siti Rahayu. 1983. Suatu Tinjauan Ringkas Sistem Pemidanaan di Indonesia. Jakarta. Akademika Pressindo.

Arif Suhartono, Said Karim, Marwati Riza. 2019. Criminal Accountability Against Illegal Civil Servant Salary Receipt in Criminal Acts of Corruption. Papua Law Journal. Volume 3 Issue 2 May 2019.

Agus Salim, Aswanto, Muhadar, Syamsuddin Muchtar. 2016. Harmonization Of Inter-Institutional Authority In Eradicate Corruption. International Journal Of Scientific And Technology Research Volume 5, Issue 10, October 2016.

Andi Muhammad Sofyan, Iin Karita Sakharina and Handar Subhandi Bakhtiar. Custody Services of The Human Rights Perspective. Quest Journal. Journal Of Research in Humanities and Social Science, Vol 5 Issue 4 (2017). 48-51 
Bambang Poernomo. 2007. Pelaksanaan Pidana Penjara Dengan Sistem Pemasyarakatan. Yogyakarta. Liberty.

Deliana. 2007. Implementasi Ide Individualisasi Pidana Dalam Pelaksanaan Pembinaan Narapidana. Jurnal Hukum Pro Justitia, Vol.25 No.2.

Edwin Sutherland. 1992. Principles of Criminology, 11th edition. New York. General Hall Inc.

Glaser, Wilkins, Title. 1977. Correctional Institution (Classification of Offenders). United States. J.B. Lippincott Company.

Herbert L Packer. 1988. The Limit of The Criminal Sanction. California. Stanford University Press.

Heru Susetyo. 2012. Laporan Tim Pengkaji Hukum Tentang Sistem Pembinaan Narapidana Berdasarkan Prinsip Restorative Justice. Badan Pembinaan Hukum Nasional Kementerian Hukum dan HAM RI.

Iqrak Sulhin. 2016. Diskontinuitas Penologi Punitif. Sebuah Analisis Genealogis Terhadap Pemenjaraan. Jakarta. Prenadamedia Group.

Koesnoen. 1961. Politik Penjara Nasional. Bandung. Sumur Bandung.

Logan dan Gaes. 1993. Meta Analysis and The Rehabilitation Of Punishment. ACJS. Vol. 10 No. 2.

Shane Bryans and Tomris Atabay. 2016. Hand Book on the Management of High-Risk Prisoners (Criminal Justice Handbookseries). New York. UNODC

Standard Minimum Rules for the Treatment of Prisoners. Adopted by the First United Nations Congress on The Prevention of Crime and the Treatment of Offenders, held at Geneva in 1955, and approved by the Economic and Social Council by its resolutions 663 C (XXIV) of 31 July 1957 and 2076 (LXII) of 13 May 1977

Zulfikri. Kendala Yang Dihadapi Lembaga Pemasyarakatan Atas Tidak Adanya Pembinaan Bagi Narapidana Korupsi. Universitas Indonesia. Jakarta

Law Number 12 of 1995 Concerning Penitentiary.

icjr.or.id, Accessed on 16 Maret 2019. 